\title{
Long-term Persistence of Infectivity of Infected Crude Extracts and Leaf Tissues of Tobacco Ringspot Virus by L-drying, Freeze-drying and Desiccation
}

\author{
Fumiyoshi FUKUMOTO*
}

Key words : tobacco ringspot virus, preservation, L-drying, freeze-drying, desiccation, protectant.

The methods of preservation of plant viruses can be grouped into freezing, freeze-drying and desiccation ${ }^{7)}$. A large number of plant viruses can be successfully preserved for a long period of time ${ }^{7)}$. However, most of the studies have been carried out based on qualitative assays of virus infectivity. Therefore, the infectivity of such preparations may subsequently decrease ${ }^{1)}$. To prevent the decrease of infectivity during storage, saccharides and amino acids etc. were sometimes added to purified preparations or crude extracts of plant viruses as protectants ${ }^{3,4,6)}$.

Tobacco ringspot virus (TRSV), which is the representative species of the genus Nepovirus, consists of isometric particles about $28 \mathrm{~nm}$ in diameter sedimenting as three components and with a bipartite RNA genome ${ }^{9)}$.

We have demonstrated that the preparations of purified TRSV were dissociated into RNA and empty protein shell by L-drying and freeze-drying and the infectivity of these preparations decreased. However, the addition of glucose or lysine enabled to preserve the virus conformation and infectivity of such preparations subjected to L-drying ${ }^{5)}$ and freeze-drying ${ }^{3)}$. Moreover, it was shown that L-drying is superior to freeze-drying ${ }^{5)}$.

Although the desiccation method, in which leaf materials are dried and stored over $\mathrm{CaCl}_{2}$ at $4^{\circ} \mathrm{C}$, is a simple and effective technique, the infectivity of preserved preparations gradually decreases ${ }^{1)}$. Thus, virus preparations using desiccated filter papers soaked into crude extracts of infected leaves supplemented with the protectants, were used as a new procedure of desiccation for preservation under various conditions. The present study was conducted to preserve the infectivity of crude extracts and leaf tissues cut in strips of TRSVinfected tobacco plants by L-drying, freeze-drying and desiccation for long-term storage.

TRSV (MAFF104031) isolated from gladiolus ${ }^{2)}$ was propagated in tobacco plants (Xanthi nc) and inoculated leaves 6-7 days after inoculation were used as samples for preservation. Crude extracts of TRSV were prepared by homogenizing infected tobacco leaves with five time $(\mathrm{v} / \mathrm{w}) 50 \mathrm{mM}$ potassium phosphate buffer (KPB), pH 7.0, containing various additives. Such preparations were filtered with a cheese cloth and used for preservation. The preparations of crude extracts $(0.1 \mathrm{ml})$ or infected leaf tissues $(0.3 \mathrm{~g})$ were L-dried and freeze-dried as previously described ${ }^{3,5)}$ and stored under several conditions. L-drying for infected leaf tissues required 4 $\mathrm{hr}$ instead of $2 \mathrm{hr}$ routinely for crude extracts. For desiccation, filter papers $(30 \times 50 \mathrm{~mm})$ were soaked into $0.1 \mathrm{ml}$ of crude extracts and desiccated in a sealed plastic container with a sufficient amount of silica gel under atmospheric pressure for $16-17 \mathrm{hr}$ at $4^{\circ} \mathrm{C}$. Then the filter papers were transferred each into new plastic bags containing silica gel $(0.5 \mathrm{~g})$ and stored under several conditions after sealing with a plastic sealer tool. The preparations of leaf tissues were also carried out the same procedure. The preparations of filter paper and leaf tissues were desiccated for only 6-7 hr when they were subjected to the infectivity assay immediately after desiccation.

For the quantitative infectivity assay, asparagus bean plants (Vigna sinensis Endle cv. Kurodane-Sanjaku) were used and evaluated as described previously ${ }^{5}$. The dried crude extracts and desiccated filter papers were diluted with $50 \mathrm{mM} \mathrm{KPB}$ to obtain a 1500 time dilution against the fresh weight of leaf tissues before preservation and used as inoculum.

The changes in the infectivity of crude extracts or leaf tissues of infected tobacco plants immediately after L-drying, freeze-drying and desiccation are shown in Table 1. The infectivity in the treated preparations of crude extracts without additives decreased to $19 \%$ (Ldrying), $0.1 \%$ (freeze-drying) and $0 \%$ (desiccation) of the values of the untreated crude extract. The addition of glucose and/or lysine regardless of treatments gave a considerable protective effect, in particular, the L-dried or freeze-dried preparations maintained a high level of infectivity in comparison with those subjected to silica gel desiccation.

Infectivity of L-dried preparations supplemented with $5-10 \%$ glucose, $1-10 \%$ lysine, or $10 \%$ glucose plus $5 \%$

\footnotetext{
* National Research Institute of Vegetables, Ornamental Plants and Tea, Ano, Mie 514-23, Japan＼cjkstart野菜・茶業試験場
} 
Table 1. Comparison of the infectivity of crude extracts and leaf tissues of infected tobacco plants after L-drying, freeze-drying and desiccation

\begin{tabular}{|c|c|c|c|}
\hline \multirow{2}{*}{$\begin{array}{l}\text { Crude extracts and } \\
\text { leaf tissues }\end{array}$} & \multicolumn{3}{|c|}{ Treatments } \\
\hline & L-drying & Freeze-drying & Desiccation \\
\hline \multicolumn{4}{|l|}{ Crude extracts } \\
\hline $5 \%$ glucose & $63 \pm 8^{a)}$ & $72 \pm 15$ & $5 \pm 2$ \\
\hline $10 \%$ glucose & $70 \pm 14$ & $\mathrm{NT}^{\mathrm{b})}$ & $33 \pm 8$ \\
\hline 1\% lysine & $66 \pm 11$ & $13 \pm 7$ & $0.5 \pm 0.2$ \\
\hline $5 \%$ lysine & $58 \pm 10$ & $73 \pm 12$ & $9 \pm 3$ \\
\hline $10 \%$ lysine & $70 \pm 14$ & NT & $23 \pm 2$ \\
\hline $10 \%$ glucose $+5 \%$ lysine & $82 \pm 17$ & NT & $47 \pm 25$ \\
\hline no additives & $19 \pm 4$ & $0.1 \pm 0.04$ & 0 \\
\hline Leaf tissues & $35 \pm 8$ & $6 \pm 2$ & $39 \pm 8$ \\
\hline
\end{tabular}

a) Numbers represent percentage of infectivity of treated preparations compared with that of untreated control. The values are averages of $4-6$ experiments.

b) NT, not tested.

lysine was $58-82 \%$ of the values of the untreated crude extract. On the other hand, by freeze-drying, the infectivity of the preparations of crude extracts supplemented with $1 \%$ lysine decreased to $13 \%$ of the values of the untreated crude extract. However, the addition of $5 \%$ lysine afforded a remarkable protection (73\% of the untreated crude extract). Infectivity of freeze-dried preparations supplemented with $5 \%$ glucose was also maintained at $72 \%$ of the control value.

In the case of desiccation, the infectivities of crude extracts supplemented with $10 \%$ glucose and $10 \%$ glucose plus $5 \%$ lysine were retained at $33 \%$ and $47 \%$ of the values of the untreated crude extract, respectively, showing that a considerable infectivity can be maintained in comparison with those supplemented with $1 \%$, $5 \%$ and $10 \%$ lysine, or $5 \%$ glucose. Infectivity of the preparations of infected leaf tissues after L-drying, freeze-drying and desiccation decreased to $35 \%, 6 \%$ and $39 \%$ of the values of the untreated crude extract, respectively.

Upon storage of L-dried preparations of crude extracts at $65^{\circ} \mathrm{C}$, the addition of $10 \%$ glucose plus $5 \%$ lysine enabled to maintain a high level of infectivity after $5 \mathrm{hr}$, which persisted even after $24 \mathrm{hr}$. The addition of $1 \%$ lysine, $5 \%$ lysine, $5 \%$ glucose or $10 \%$ glucose also afforded a considerable protective effect. The preparations supplemented with $10 \%$ lysine lost their infectivity after $2.5 \mathrm{hr}$. The infectivity in L-dried preparations of crude extracts without additives and leaf tissues was maintained only slightly after $5 \mathrm{hr}$.

Upon storage at $35^{\circ} \mathrm{C}$, the protective effect of glucose and lysine in the L-dried preparations showed a similar tendency to that of the preparations stored at $65^{\circ} \mathrm{C}$. The addition of $10 \%$ glucose plus $5 \%$ lysine afforded maximum protection, and in such preparations a high level of infectivity was maintained for 6 months (Fig. 1).

As in the case of L-drying, freeze-dried preparations of crude extracts were preserved to assess the protective effect of glucose and lysine at various concentrations at $35^{\circ} \mathrm{C}$ and $65^{\circ} \mathrm{C}$. Upon the storage at $65^{\circ} \mathrm{C}$, the

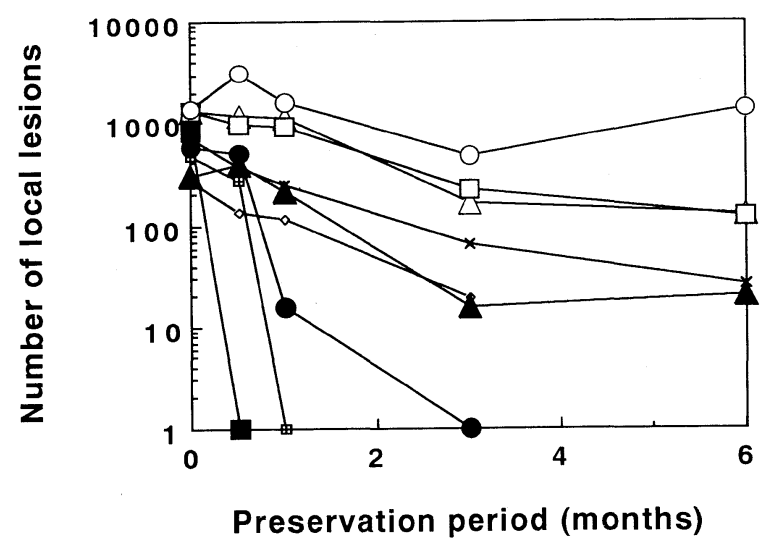

Fig. 1. Effect of various additives on infectivity of crude extracts and leaf tissues of infected tobacco plants subjected to L-drying (LD), freeze-drying (FD) or desiccation (DES) and preserved at $35^{\circ} \mathrm{C}$. Number of local lesions: total number of local lesions in 16 primary leaves of eight asparagus bean plants. $\triangle: 5 \%$ glucose (LD), $\square: 10 \%$ glucose (LD), $\times: 5 \%$ lysine (LD), ^ : 5\% lysine (FD), $\bigcirc: 10 \%$ glucose $+5 \%$ lysine (LD), $\mathbf{- 1 0}: 10 \%$ glucose $+5 \%$ lysine (FD), $\bullet: 10 \%$ glucose $+5 \%$ lysine (DES), $\diamond:$ no additives (LD), $\boxplus$ : leaf tissue (LD).

addition of $3 \%$ or $5 \%$ lysine afforded maximum protective effect in some preparations, and in such preparations the infectivity was well maintained even after $5 \mathrm{hr}$. The addition of $1 \%$ lysine or $1-10 \%$ glucose was less effective than that of $3 \%$ or $5 \%$ lysine. Although the infectivity of the freeze-dried preparations supplemented with $10 \%$ glucose plus $5 \%$ lysine, which gave a highly protective effect immediately after L-drying, remained higher than that with $5 \%$ lysine after one hr, the infectivity was completely lost after $5 \mathrm{hr}$. The infectivity of preparations of crude extracts supplemented with $1 \%$ lysine or $1 \%, 5 \%$ or $10 \%$ glucose was lower than that with the addition of $5 \%$ lysine, and the infectivity disappeared within two hr. Infectivity of the freeze-dried 


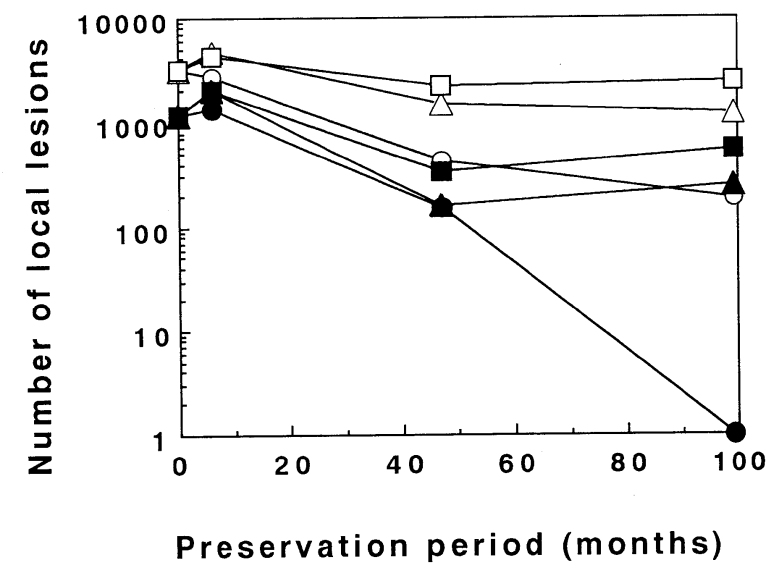

Fig. 2. Effect of $10 \%$ glucose plus $5 \%$ lysine on infectivity of crude extracts of infected tobacco plants subjected to L-drying (LD) and desiccation (DES) and preserved at various temperatures. Number of local lesions: see legend for Fig. 1. $\bigcirc: \mathrm{LD}$ at $4^{\circ} \mathrm{C}, \bullet: \mathrm{DES}$ at $4^{\circ} \mathrm{C}, \triangle: \mathrm{LD}$ at $-20^{\circ} \mathrm{C}, \triangle: \mathrm{DES}$ at $-20^{\circ} \mathrm{C}, \square: \mathrm{LD}$ at $-70^{\circ} \mathrm{C}$, : DES at $-70^{\circ} \mathrm{C}$.

preparations without additives or infected leaf tissues also decreased rapidly, and was lost within $10 \mathrm{~min}$.

Upon storage at $35^{\circ} \mathrm{C}$, the infectivity of freeze-dried preparations of crude extracts supplemented with $5 \%$ lysine gradually decreased, and slightly persisted after 6 months (Fig. 1). On the other hand, infectivity in the preparations supplemented with $10 \%$ glucose, $10 \%$ glucose plus $5 \%$ lysine or lacking additives could not be detected after half a month of storage.

By desiccation with silica gel, the addition of $10 \%$ glucose plus $5 \%$ lysine in the crude extracts enabled to maintain a high level of infectivity $24 \mathrm{hr}$ after the preservation at $65^{\circ} \mathrm{C}$ compared with the addition of $5 \%$ glucose, $10 \%$ glucose or $1-10 \%$ lysine, and infected leaf tissues. During the storage at $35^{\circ} \mathrm{C}$, the use of various additives also resulted in a similar protection. The preparations supplemented with $10 \%$ glucose plus $5 \%$ lysine, which gave a maximum protective effect, showed low infectivity after one month (Fig. 1). Therefore, the infectivity of the preparations preserved by desiccation was very low in comparison with L-drying. The effect of the addition of $5 \%$ or $10 \%$ glucose or $5 \%$ lysine was negligible, and the infectivity was lost after storage for half a month. Infected leaf tissues preserved by desiccation also showed the same level of infectivity.

To evaluate the level of infectivity at low temperatures during long-term preservation, the inoculum of preserved preparations was inoculated to test plants.

In the case of L-drying, almost no decrease of infectivity could be observed in the preparations supplemented with $10 \%$ glucose plus $5 \%$ lysine during storage for 99 months at $-70^{\circ} \mathrm{C}$ as well as at $-20^{\circ} \mathrm{C}$. Although the infectivity of the preparations preserved at $4^{\circ} \mathrm{C}$ decreased gradually, the infectivity was well maintained (Fig. 2). However, the preparations without

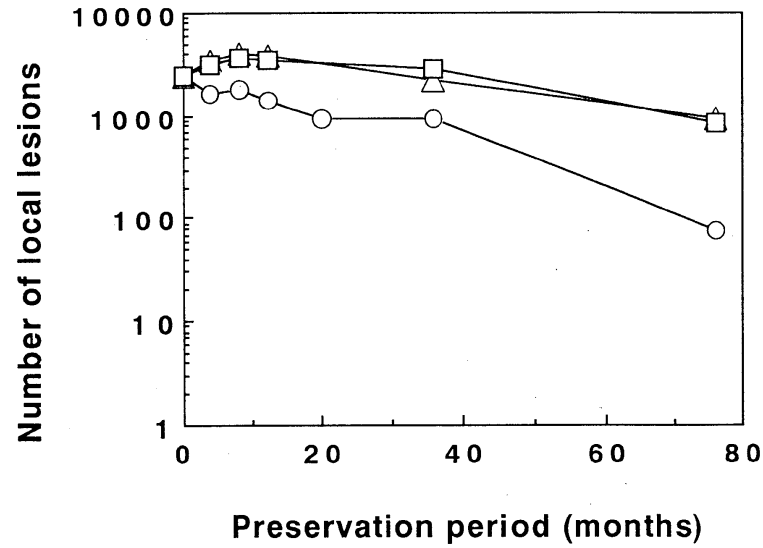

Fig. 3. Effect of $5 \%$ lysine on infectivity of crude extracts of infected tobacco plants subjected to freeze-drying and preserved at various temperatures. Number of local lesions: see legend for Fig. $1 . \circ$ : at $4^{\circ} \mathrm{C}, \Delta$ : at $-20^{\circ} \mathrm{C}, \square$ : at $-70^{\circ} \mathrm{C}$.

additives showed a marked decrease of infectivity at $4^{\circ} \mathrm{C}$ during storage for 99 months, and the infectivity of the preparations preserved at $-20^{\circ} \mathrm{C}$ or $-70^{\circ} \mathrm{C}$ also decreased considerably. During the storage of L-dried infected leaf tissues at $-20^{\circ} \mathrm{C}$ or $-70^{\circ} \mathrm{C}$, a slight decrease of infectivity was observed after 99 months, while the preparations preserved at $4^{\circ} \mathrm{C}$ showed a marked decrease of infectivity.

In the case of freeze-drying, the infectivity of the preparations supplemented with $5 \%$ lysine decreased slightly its during preservation for 76 months at $-20^{\circ} \mathrm{C}$ or $-70^{\circ} \mathrm{C}$, while the infectivity of the preparations preserved at $4^{\circ} \mathrm{C}$ markedly decreased (Fig. 3). The freeze-dried preparations without additives and of infected leaf tissues completely lost their infectivity within 18 months at $4^{\circ} \mathrm{C}$. Infectivity of such preparations preserved at $-20^{\circ} \mathrm{C}$ or $-70^{\circ} \mathrm{C}$ was well maintained, although the infectivity of the preparations immediately after freeze-drying decreased.

Upon storage at $4^{\circ} \mathrm{C}$, infectivity in the desiccated preparations of filter papers supplemented with 10\% glucose plus $5 \%$ lysine decreased gradually, and completely disappeared after 99 months of preservation. However, the preparations preserved at $-20^{\circ} \mathrm{C}$ or $-70^{\circ} \mathrm{C}$ maintained a considerable infectivity (Fig. 2), although the infectivity of such preparations markedly decreased immediately after desiccation as described previously. Infectivity of infected leaf tissues desiccated was well maintained during storage for 6 months at $4^{\circ} \mathrm{C}$, but was completely lost after 47 months. However, upon storage at $-20^{\circ} \mathrm{C}$ or $-70^{\circ} \mathrm{C}$, the preparations of infected leaf tissues desiccated maintained their infectivity even after 99 months, although the infectivity of such preparations was lower than that of preparations supplemented with $10 \%$ glucose plus $5 \%$ lysine.

In the drying process of purified TRSV, L-drying caused less damage than freeze-drying ${ }^{5}$. Similarly, in the present study, the infectivity in the preparations of 
L-dried crude extracts remained higher than that of freeze-dried and desiccated preparations (Fig. 1). However, the addition of glucose and/or lysine suppressed the damage from L-drying or feeeze-drying, and such preparations retained a high level of infectivity. In the case of silica gel desiccation, the maintenance of infectivity depended on the concentrations of glucose and lysine, and higher concentrations induced effective protection, although desiccation was inferior to L-drying or freeze-drying. By desiccation, the viral peaks in the purified preparations supplemented with glucose or lysine were not recovered from filter papers based on the profiles of sucrose density gradient centrifugation (unpublished observation). The results after desiccation of crude extracts of infected plants were correlated with those of purified preparations.

Upon storage at high temperatures, the L-dried preparations supplemented with $10 \%$ glucose plus $5 \%$ lysine showed the highest protection (Fig. 1). Consequently, it is suggested that L-drying is superior to freeze-drying and desiccation as in the case of purified TRSV. However, during the preservation for several years at a low temperature below $-20^{\circ} \mathrm{C}$, there were slight differences in the infectivity of the preparations supplemented with glucose and/or lysine among the three methods. Therefore, preservation for a longer period of time may be necessary to identify marked differences. However, the infectivity of the L-dried preparations of crude extracts supplemented with $10 \%$ glucose plus $5 \%$ lysine was stably preserved. The infectivity of the freeze-dried preparations supplemented with $5 \%$ lysine decreased gradually even at $-20^{\circ} \mathrm{C}$ and $-70^{\circ} \mathrm{C}$. On the other hand, desiccated preparations supplemented with $10 \%$ glucose plus $5 \%$ lysine could be preserved considerably for a long period of time below $-20^{\circ} \mathrm{C}$ (Fig. 2), although the infectivity of such preparations decreased to $39 \%$ immediately after desiccation. Mckinney $e t$ al. ${ }^{8)}$ demonstrated that TRSV-infected tobacco plants desiccated and kept at $1^{\circ} \mathrm{C}$ for 17 years maintained their infectivity, although the level of infectivity was unknown since only a qualitative assay was carried out. However, desiccation of crude extracts supplemented with effective protectants using filter papers was superior to desiccation of leaf tissues based on quantitative assay of infectivity in the present study. This technique is simple, effective and practical, because no apparatus for drying process is required. The methods for the preservation of TRSV should be selected to fulfill the respective objectives, although L-drying is superior to freeze-drying or desiccation for long-term preservation.

\section{Literature cited}

1. Bos, L. (1977). Persistence of infectivity of three viruses in plant material dried over $\mathrm{CaCl}_{2}$ stored under different conditions. Neth. J. Plant Pathol. 83 : 217-220.

2. Fukumoto, F., Ito, Y. and Tochihara, H. (1982). Viruses isolated from gladiolus in Japan. Ann. Phytopathol. Soc. Jpn. $48: 68-71$.

3. Fukumoto, F. and Tochihara, H. (1984). Effect of various additives on the long-term preservation of tobacco ringspot and radish mosaic viruses. Ann. Phytopathol. Soc. Jpn. $50: 158-165$.

4. Fukumoto, F. and Tochihara, H. (1992). Similarity of the conditions for freeze-drying preservation among three cucumoviruses. Ann. Phytopathol. Soc. Jpn. 58: 366-372.

5. Fukumoto, F. and Tochihara, H. (1996). Comparison between L-drying and freeze-drying methods for the preservation of purified tobacco ringspot virus. Ann. Phytopathol. Soc. Jpn. $62: 45-48$.

6. Hollings, M. and Stone, O.M. (1970). The long-term survival of some plant viruses by preserved lyophilization. Ann. Appl. Biol. 65 : 411-418.

7. Mckinney, H.H. and Silber, G. (1968). In Method of preservation and storage of plant viruses: Methods in Virology, Vol. 4 (Maramorosch, K. and Koprowski, M. eds.), Academic Press, London and New York, pp. 491501.

8. Mckinney, H.H. and Silber, G. and Gleely, L.W. (1965). Longevity of some plant viruses stored in chemically dehydrated tissue. Phytopathology 55 : 1043-1044.

9. Stace-Smith, R. (1985). Tobacco ringspot virus. AAB Descriptions of Plant Viruses. No. 309.

\section{和 文 摘 要}

福本文良：L-乾燥, 凍結乾燥およびシリカゲル乾燥法を用い た夕バコ輪点ウイルス感染葉の粗汁液と組織片による病原性の 長期保存

タバコ輪点ウイルスの感染葉粗汁液と組織片を用いて，L-乾 燥, 凍結乾燥およびシリカゲル乾燥法による病原性の長期保存 性を調べた。それぞれの処理で粗汁液の病原性は無処理に比べ て 19\%，0.1\%および $0 \%$ に低下した。10\%ぶどう糖と $5 \%$ リジン の両添加物を加えた標品の L-乾燥およびシリカゲル乾燥法に よる処理後の病原性は高く維持され, それぞれ $82 \%$ と $47 \%$ であ った。一方, 凍結乾燥の場合, $5 \%$ リジンの添加で $73 \%$ であった。 高温における保存試験でも, それらの添加物は病原性の低下を 抑制し, 保護効果は L-乾燥, 凍結乾燥, シリカゲル乾燥法の順 であった。10\%ぶどう糖と5\%リジンを添加した L-乾燥標品で は, 病原性はー $20^{\circ} \mathrm{C}$ 以下で 99 か月間安定して保存された。シリ カゲル乾燥標品でも長期保存が可能であった。

(Received March 20, 1995; Accepted June 26, 1995) 